\title{
Exotic plant invasions to the mediterranean region of Chile: causes, history and impacts
}

\author{
Invasión de plantas exóticas en la región mediterránea de Chile: causas, historia e impactos
}

\author{
JAVIER A. FIGUEROA*, SERGIO A. CASTRO, PABLO A. MARQUET \& FABIAN M. JAKSIC \\ Centro de Estudios Avanzados en Ecología \& Biodiversidad, Pontificia Universidad Católica de Chile, Santiago \\ CP 6513677, Chile \\ *Corresponding author: jfiguero@bio.puc.cl
}

\begin{abstract}
We review the literature on patterns, causes, processes and impacts of exotic plants, primarily in the mediterranean region of Chile, considering three major non-independent drivers of the invasion process: (a) Availability of exotic species propagules, (b) attributes of the local communities in which exotic species establish and through which they will eventually spread out, and (c) attributes of exotic species that either facilitate or constraint their spread into new sites. Regarding availability of propagules, central Chile matorral presents the communities with the greatest incidence of naturalized herbs, followed by the sclerophyllous forest and the espinal scrubland in the coastal range. In contrast, north-central communities have lower numbers and proportions of naturalized species of herbs in their seed banks. Availability and persistence of naturalized herbs do not differ between aboveground vegetation and seed bank. Regarding attributes of local communities associated with the establishment and the spread of exotics, grazing regime and land use emerge as the most prominent causes that render them more prone to invasion by exotics. Evidence on the effect of the fire regime is contradictory and native species richness does not seem to be an important factor. Regarding attributes of exotic species seeds, results suggest that naturalized annuals germinate within a wide temperature range, are highly resistant to cold and dry conditions, and show some degree of physiological dormancy. Additionally, naturalized annuals are highly tolerant to poor soils, but are generally intolerant to shade. These general attributes have largely determined the invasion process in the mediterranean region of Chile. Historical data indicate that an important number of exotic species were intentionally introduced, and that the spread of exotic is uncontrolled. It has been demonstrated that arrival time of exotics is of great relevance to understand present day spread of exotics in Chile, independent of their biogeographic origin. Exotic species may cause strong disruptions of ecosystem processes and functions in Chile, as exemplified by exotic tree plantations, which have altered soil chemistry, nutrient cycling, water cycle, hydrology, microclimate, and fire frequency and intensity.
\end{abstract}

Key words: exotic species, plant invasions, naturalized plants, invasion history, ecosystem disruption.

\section{RESUMEN}

Revisamos la literatura sobre patrones, causas, procesos e impactos de las plantas exóticas, principalmente en la región mediterránea de Chile, considerando tres factores determinantes del proceso de invasión: (a) Disponibilidad de propágulos de las especies exóticas, (b) atributos de las comunidades locales en las cuales las especies exóticas se establecen y a partir de las cuales eventualmente se expanden, y (c) atributos de las especies exóticas que facilitan o restringen su expansión a nuevos sitios. Con relación a la disponibilidad de propágulos, el matorral de Chile central presenta las comunidades con la mayor incidencia de hierbas naturalizadas, seguido por el bosque esclerófilo y el espinal de la Cordillera de la Costa. En contraste, las comunidades al norte de Chile central tienen menores números y proporciones de hierbas naturalizadas en sus bancos de semilla. La disponibilidad y persistencia de hierbas naturalizadas no difiere entre la vegetación emergida y el banco de semillas. En cuanto a los atributos de las comunidades locales, asociadas al establecimiento y expansión de las especies exóticas, tanto el régimen de pastoreo como el uso de la tierra emergen como los factores más prominentes en hacerlas susceptibles a la invasión por exóticas. La evidencia sobre el efecto del régimen de incendios es contradictoria y la riqueza de especies nativas tampoco aparece como un factor importante. Con relación a la atributos de las semillas de especies exóticas, los resultados sugieren que las anuales naturalizadas germinan dentro de un amplio rango de temperaturas, que son altamente resistentes a las condiciones frías y secas, y que muestran un cierto grado de latencia fisiológica. Además, las anuales naturalizadas son altamente tolerantes a los suelos pobres, y generalmente intolerantes a la sombra. Estos atributos generales han sido determinantes en el proceso de invasión de la región 
mediterránea de Chile. Los datos históricos indican que un número importante de especies exóticas fueron introducidas intencionalmente, y que su expansión no está controlada. Se ha demostrado que la fecha de arribo de las especies exóticas es de gran relevancia para entender su actual dispersión en Chile, independientemente de su origen biogeográfico. Las especies exóticas pueden causar grandes perturbaciones de procesos y funciones ecosistémicas en Chile, tal como lo ejemplifican las plantaciones de árboles exóticos, que han alterado la química del suelo, el ciclaje de nutrientes, el ciclo del agua, la hidrología, el microclima, y la frecuencia e intensidad de incendios.

Palabras clave: especies exóticas, invasiones de plantas, plantas naturalizadas, historia de invasión, perturbaciones ecosistémicas

\section{INTRODUCTION}

In the past five centuries, the rate of interchange of fauna and flora among distant regions of the planet has increased considerably (D’Antonio \& Vitousek 1992, Lodge 1993, Williamson 1996). Either intentionally or inadvertently species of a wide spectrum of taxonomic and geographic origins have been relocated by man, by facilitating their dispersal through previously insurmountable biogeographic barriers (Mack et al. 2000, Sakai et al. 2001). Once in their new habitat, introduced species may establish viable populations (Lodge 1993, Kolar \& Lodge 2001) and in some cases, surpass the abundance and geographic distribution of comparable native species (Lodge 1993).

Although the existence of biological invasions had been noted for some time (Darwin 1872, Elton 1958), it has only been in the last two decades that a profound interest has developed, owing to the important ecological, economic and human health impacts of exotic species (Bright 1996, Sakai et al. 2001, Mooney \& Hobbs 2000, Pimentel et al. 2000, Mooney et al 2001). At the ecological level, invasive species are capable of modifying the patterns of abundance and distribution of native species in the community (Williamson 1996), to the point of causing the local extinction of native populations (Vitousek et al. 1996). This fact becomes more worrying if we consider that present day rates of species introductions are unprecedented in history, and they are far from being under control (Williamson 1996). The existing evidence suggests that greater changes in global diversity can be expected if species introductions are not controlled, especially in the species-rich mediterranean-type regions of the planet (Sala et al. 2000).

Vascular plants are among the most ubiquitous invaders of the biosphere (Elton 1958, D'Antonio \& Vitousek 1992, van Auken 2000). The majority of these plants have been introduced for agricultural, sylvicultural, ornamental, or medicinal purposes (Williamson
1996), but many have been introduced accidentally (Newsome \& Noble 1986). In Chile, close to 700 exotic vascular plant species are considered weeds in agro-ecosystems (Matthei 1995), and many of them have also established in natural and semi-natural environments (Montenegro et al. 1991, Arroyo et al. 2000). The majority of these are concentrated in the central region of Chile (Matthei 1995), which below 2,000 m elevation corresponds to the mediterranean-type climate area of the country (di Castri \& Hajek 1976). Mediterranean ecosystems here and elsewhere are eco-regions with high floristic richness and endemism on a global level (Cowling et al. 1996, Arroyo et al. 1999, Myers et al. 2000).

Despite the importance of invasions in Chilean mediterranean-type ecosystems, little is known about the underlying causes of these invasions, historical processes, and their consequences for native species and ecosystem functions. Here, we provide an exhaustive review of the relevant literature, with the purpose of assessing what we know and what are the major gaps in our knowledge of the invasion processes in Chilean mediterranean-type ecosystems. For methodological and analytical purposes we concentrate on the causes of invasions and naturalizations in central Chile by focusing on three major non-independent drivers associated to the spread of exotic species (Fig. 1). We identify propagule availability, attributes of local communities, and attributes of exotic species as the three major interacting components of the invasion processes in central Chile. The establishment and spread of exotic species depends on an initial availability of propagules that will initiate the process of invasion within a local community. For this initial colonization to be successful a match between the attributes of the local community, which define its invasibility (e.g., disturbance regime, abiotic and biotic characteristics) and the ecological and physiological requirements and tolerances of the exotic species, which define their invasiveness, is required. Depending 
on this, a given species will either establish and reproduce in a local community or become locally extinct. Each result will affect the availability of propagules, thus recursively affecting the process of invasion through time. In the following paragraphs we elaborate on what we know about these interacting components of the invasion process and explore the effects of invasive plants on different ecosystem functions in Chilean mediterranean ecosystems. Finally, we identify areas of knowledge where research is scarce and/or urgent for a better understanding of the ecological consequences of plant invasions in mediterranean-type ecosystems of Chile.

\section{AVAILABILITY OF EXOTIC PLANT PROPAGULES}

\section{Established plant pool}

Naturalized species in central Chile amount to $18 \%$ of the total flora and to $27 \%$ in the case of herbs (Arroyo et al. 2000). However, this percentage varies at the scale of local communities in central Chile (Table 1). For instance, the frequency of naturalized herbs (e.g., Erodium spp., Medicago polymorpha, Malva nicaensis) was close to $45 \%$ of the established vegetation in a managed "matorral" (Las Cardas, $30^{\circ} \mathrm{S}$ ), from where domestic herbivores were excluded for five years (Lailhacar \& Aylwin 1988, Lailhacar \& Torres 2002, Torres 1999). Further, in a pre-montane sclerophyllous matorral (San Carlos de Apoquindo, $\left.33^{\circ} \mathrm{S}\right)$, naturalized herbaceous species (e.g., E. cicutarium, Vulpia bromoides, Anthriscus caucalis, Geranium robertianum), represented approximately $50 \%$ of the taxa established aboveground (Figueroa et al. in press). Instead, in a protected semiarid thornscrub of northcentral Chile (Aucó, $31^{\circ} \mathrm{S}$ ), only $20 \%$ of ephemeral species recorded (e.g., E. botrys, E. malacoides, Galium aparine) corresponded to naturalized species (Gutiérrez et al. 2000). In sum, the available evidence suggests that the central Chilean matorral is one of the communities with the greatest incidence of naturalized herbaceous flora. Other authors have suggested the same for the sclerophyllous forest and the espinal of the Coastal Mountain Range, with frequencies of naturalized species above $50 \%$ (Montenegro et al. 1991).

\section{Propagules stored in the soil}

Assessing the availability of naturalized plants for an area requires not only knowing where the flora came from in an established community, but also information on the propagule reserve in the soil (Thompson \& Grime 1979, Holmes \& Cowling 1997). For instance, the percentage of naturalized herbs in the seed bank of the pre-montane sclerophyllous matorral at San Carlos de Apoquindo $\left(33^{\circ} \mathrm{S}\right)$ represents approximately 55 $\%$ of the total number of herbaceous taxa (Figueroa et al. in press). Still, a number of naturalized species present in the seed bank were not recorded among the established plants at the site during the same season (e.g., Aphanus arvensis, Nasturtium officinale, Polygonum aviculare, Portulaca grandiflora). Close to $60 \%$ of the total density of buried seeds, including native and naturalized herbs in exposed successional areas belonged to the exotic grass Vulpia bromoides (Figueroa et al. in press). On the other hand, a managed grassland of central Chile (Rinconada de Maipú, 32 ${ }^{\circ}$ S) (Olivares et al. 1994), had almost twice the concentration of buried seeds and greater dominance of naturalized herbs in the seed bank than the pre-montane matorral of San Carlos de Apoquindo. Olivares et al. (1994) identified nine taxa in the seed bank, of which eight were naturalized herbs (E. botrys, E. cicutarium, E. malacoides, Avena barbata, Hordeum murinum, Vulpia sp., Trifolium glomeratum and Medicago polymorpha). In a deciduous matorral of semiarid central Chile (Fray Jorge, $30^{\circ} \mathrm{S}$ ), naturalized annuals (e.g., E. cicutarium, $M$. nicaensis) represented about $20 \%$ of the total number of seeds (Gutiérrez \& Meserve 2003). A minor representation of naturalized species was found in the seed bank of a thorn-scrub matorral in north-central Chile with high presence of ephemeral native species (Table 1), where the most abundant exotics belonged to Erodium spp. (Gutiérrez et al. 2000). Finally, available information shows that north-central Chilean communities have smaller richness and proportion of naturalized herbs in the seed bank than do central Chilean communities. Nevertheless, there is not enough evidence to suggest that the naturalized herb availability and persistence differs strongly between the established vegetation aboveground and the seed bank, perhaps with the exception of the steppe matorral of northcentral Chile (see Table 1).

\section{ATTRIBUTES OF THE LOCAL COMMUNITY}

Diverse factors in the native community may facilitate the establishment of exotic plants 


\section{TABLE 1}

Percent of exotic herb species recorded in communities of central Chile with regard to the total number of herbs established on the ground and stored in the seed bank. $\mathrm{Nd}=$ no data. Percentages were obtained from lists of species (flora) published by the authors cited, with exception of Sax (2002a) who reported the mean number of plants. All authors presented data at a medium- and small-size scale, with exception of Arroyo et al. (2000) who recorded at a regional scale

Porcentaje de hierbas exóticas establecidas en el suelo y almacenadas en el banco de semillas, considerando el número total de hierbas registradas en comunidades de Chile central. $\mathrm{Nd}=$ no hay datos. Los porcentajes fueron obtenidos desde las listas de especies que los autores publicaron, a excepción de Sax que informó el número promedio de plantas. Todos los autores presentan datos a una escala de tamaño mediano y pequeño, a excepción de Arroyo que informó a una escala regional

\begin{tabular}{lrcrl}
\hline Community & Location & Exotics on the ground & $\begin{array}{c}\text { Exotics in the } \\
\text { seed bank }\end{array}$ & Reference \\
\hline Deciduous matorral & $30^{\circ} \mathrm{S}$ & 21 & 19 & Gutiérrez \& Meserve (2003) \\
Atriplex matorral & $30^{\circ} \mathrm{S}$ & 45 & $\mathrm{Nd}$ & Lailhacar \& Torres (2002) \\
Steppe matorral & $31^{\circ} \mathrm{S}$ & 20 & 12 & Gutiérrez et al. (2000) \\
Managed grassland & $32^{\circ} \mathrm{S}$ & $\mathrm{Nd}$ & 88 & Olivares et al. (1994) \\
Evergreen matorral & $33^{\circ} \mathrm{S}$ & 50 & 55 & Figueroa et al. (in press) \\
Xeric matorral & $33^{\circ} \mathrm{S}$ & 47 & $\mathrm{Nd}$ & Sax (2002a) \\
Acacia espinal & Coastal range & 50 & $\mathrm{Nd}$ & Montenegro et al. (1991) \\
Central Chile & $33-37^{\circ} \mathrm{S}$ & 27 & $\mathrm{Nd}$ & Arroyo et al. (2000) \\
\hline
\end{tabular}

(Hobbs 2000). For instance, the burning of native vegetation (Richardson et al. 1990, D'Antonio 2000, D'Antonio et al. 2001), grazing pressure (Whisenant \& Uresk 1990, Stohlgren et al. 1999a, Holmgren 2002), changes in land use (Rudnicky \& McDonnell 1989, Kowarik 1990, Rapoport 1993, 2000, Drayton \& Primack 1996) and low diversity of the native community (Elton 1958) may increase the susceptibility to invasion by exotic plants. Each of these factors is considered in more detail below, with regard to information available from central Chile.

\section{Fire regime}

The intentional burning of vegetation is a widely used agricultural technique that has been applied since the Spanish conquest (Aronson et al. 1998). The natural present-day vegetation did not evolve in response to natural fires occurring during dry summers, as it did in other mediterranean-type climate regions (Muñoz \& Fuentes 1989). It is widely recognized that fires in the matorral are either directly or indirectly caused by humans (CONAF 1998, Montenegro et al. 2002). At the same time, the first reports of naturalized plants in this region are contemporary with the quick spread of European culture in Chile. Notwithstanding, the introduction of plants and the use of fire are not clearly related (Holmgren 2002) but few experimental studies exist on the effects of fire on the composition and abundance of naturalized plants in Chile (Keeley \& Johnson 1977, Avila et al. 1981, Holmgren 2000a,b). Exotic invasive grasses have replaced vast regions of evergreen matorral in central Chile (Holmgren 2002), which is the likely underlying factor of high frequency of fires (Kunst et al. 2003). There are suggestions that invasive annual populations rebound quickly after fires whereas native perennials recover slowly, but there is no agreement among authors on the importance of fires in the invasibility of communities in central Chile.

On one hand, in burned woodlands of Acacia caven, one year after a wildfire, 44,200 seedlings per $\mathrm{m}^{2}$ were recorded of the naturalized annuals Vulpia, Koeleria and Bromus (Trabaud 1991). Further, Avila et al. (1981) reported that fire increased the abundance of naturalized herbs such as Erodium cicutarium, E. botrys, Stellaria cuspidata, Discurainia cumingiana, Matricaria chamonilla and Avena barbata in a matorral on the Coastal Mountain Range (Cuesta Barriga, $\left.33^{\circ} \mathrm{S}\right)$. Recently, Sax (2002a) also showed that fire favored exotic species richness and cover over native species in a xeric matorral. The conclusions of these authors are concordant with observations made in southern France and western North America, where naturalized species that also occur in Chile, enhance the frequency of fires (e.g., Arundo donax, Bromus 
madritensis, B. tectorum, Carduus pycnocephalus, E. cicutarium, Geranium robertianum, Schismus barbatus, and Sonchus asper) (Trabaud 1991, Dukes \& Mooney in this special issue).

Nevertheless, there are contradictory data as well. For instance, Keeley \& Johnson (1977) and Holmgren et al. (2000a,b) showed that fire in the Chilean matorral does not have differential effects on the relative abundance and composition of exotic (e.g., Lophocloa cristata, E. cicutarium, Medicago polymorpha) and native herbs (e.g., Bromus berterianus, Amsinkia hispida). Likely, the opposed views on the effects of fire are due to confounding factors that affect community invasibility (e.g., grazing, land use, species richness) and whose interaction determine the establishment of exotic and native plant species. All these effects are difficult to sort out with traditional methods of vegetation sampling (Stohlgren et al. 1999b). Thus, this is a subject that needs to be studied further by using experiments that control for multiple confounding factors.

\section{Grazing regime}

Rabbits, together with cattle, goats, and horses, introduced from Europe, are widely distributed in the country and represent the principal herbivores in the matorral (Jaksic 1998). Particularly, European rabbits have been shown to arrest the process of succession in the native matorral (Fuentes et al. 1983). Although there is no conclusive evidence demonstrating that rabbits reduce the richness of native plants, their relative abundance is surely reduced with respect to that of naturalized species (Sáiz \& Ojeda 1988, Holmgren et al. 2000a). Specifically, when matorral plots were subjected to rabbit grazing, the native grass Bromus berterianus proved to be the most affected species, losing $30 \%$ more biomass than the introduced grass Lophocloa cristata (Holmgren et al. 2000a). In contrast to rabbits, native small mammals have more limited effects on matorral vegetation (Fuentes et al. 1983).

Rabbits prefer to graze on exposed sites lacking shrub cover (Jaksic 1998). As the diet of rabbits consists mostly of native herbs, this herbivore may be facilitating the growth of naturalized annual herbs in open spaces and outside shrubs (Jaksic \& Fuentes 1980). This may have resulted in the presently observed spatial segregation, with perennial native herbs restricted to protected sites under the shrub canopy, and with naturalized annual herbs common on exposed sites outside shrubs
(Jaksic \& Fuentes 1980). Nevertheless, this spatial segregation of invasive versus native annual plants does not always occur (Table 2), and could be the result of differences in nutrient availability and light. For example, in a study of a semi-arid grassland (Las Cabras, $30^{\circ}$ $\mathrm{S})$, from where livestock had been excluded but that was exposed to grazing by rabbits, the naturalized annual species Medicago polymorpha and Erodium moschatum were concentrated below the canopy or in the periphery of Cassia coquimbensis and of Acacia caven, respectively (Lailhacar \& Aylwin 1988). In these abandoned grasslands, the spatial distribution of annual herbs was associated rather to organic matter contents of soils, Nitrogen availability, and soil $\mathrm{pH}$ (Lailhacar \& Aylwin 1988), as well as to water availability, and shrub species cover and identity (Lailhacar et al. 19991', Torres 1999, Lailhacar \& Torres 2002).

With respect to exotic livestock, there is consensus that its presence has enhanced naturalized spread to the detriment of native perennials and annuals (Lailhacar et al. 19991, Holmgren et al. 2000a,). Further, the introduction and management of livestock may have provoked the replacement of native hemicryptophytes by both native and naturalized annuals, which have the advantage of resisting the most stressful periods of the year as seeds (Lailhacar 1986). Most authors concur that naturalized plants of Eurasian origin are better adapted and have greater tolerance to grazing by livestock because they evolved under the pressure of indigenous Eurasian livestock (Holmgren 2002).

In sum, it is evident that grazing by livestock and rabbits has facilitated the spread of naturalized plants in central Chile (Jaksic \& Fuentes 1980, Lailhacar 1986, Lailhacar \& Aylwin 1988, Sáiz \& Ojeda 1988, Holmgren et al. 2000a, Holmgren 2002) increasing both species invasiveness and community invasibility in central Chile. However, the putative effect of rabbits in promoting the spatial segregation of native perennial herbs and introduced annuals is not conclusive.

\section{Land use}

In Chile, the richness of exotic flora is directly related to the density of roads (e.g., Cotula

\footnotetext{
${ }^{1}$ LAILHACAR S, C TORRES \& P AZÓCAR (1999) The effect of Atriplex species and rainfall variations on the herbaceous stratum in arid Chile. VI International Rangeland Congress. Townsville, Queensland, Australia.
} 
TABLE 2

Main establishment site for exotic annual plants in matorral communities of central Chile

Principal sitio de establecimiento de plantas anuales exóticas en comunidades de matorral de Chile central

\begin{tabular}{llll}
\hline Community & Exotic species & Establishment site & Reference \\
\hline Evergreen matorral & Anthriscus caucalis & Under the canopy & Figueroa et al. (in press) \\
Evergreen matorral & Geranium robertianum & Under the canopy & Figueroa et al. (in press) \\
Cassia matorral & Medicago polymorpha & Under the canopy & Lailhacar \& Aylwin (1988) \\
Acacia matorral & Erodium moschatum & Canopy's edge & Lailhacar \& Aylwin (1988) \\
Atriplex matorral & Erodium moschatum & Canopy's edge & Torres (1999) \\
Atriplex matorral & Malva nicaensis & Indifferent & Torres (1999) \\
Atriplex pruned matorral & Erodium moschatum & Under the canopy & Torres (1999) \\
\hline
\end{tabular}

australis, Hypochaeris radicata), and of urban (e.g., Lactuca serriola) and cultivated soils (e.g., Raphanus sativus) (Arroyo et al. 2000). Results of a comparative analysis between central Chile and California, and comparisons among regions of Chile, suggest that plant naturalization is more frequent in areas of greater urban population growth, and contrary to expectations, the amount of agricultural land does not have a significant effect (Matthei 1995, Arroyo et al. 2000). This pattern could emerge because roads facilitate the spread of exotic plants, and urban centers represent storage sites for seeds that come from external and internal markets.

Likewise, at the landscape scale, the distribution of exotic plants was studied on rural roads in two national parks in the Andean Cordillera $\left(39^{\circ} \mathrm{S}\right)$ by Pauchard \& Alaback (2004). This study showed that rural roads are functional corridors and serve as sources of exotic propagules that facilitate the spread of exotic species (e.g., Hypochaeris radicata, Agrostis capillaris, Rumex acetosella, Lotus uliginosus) into protected native communities. Therefore, it is important to consider that changes in land use may alter and modify the processes of invasion and availability of exotic plants (Hobbs 2000, Pauchard \& Alaback 2004).

Notwithstanding the above, studies in central Chile have not yet evaluated the mechanisms underlying the spread of exotic species on converted soils. Changes in land use are directly correlated with disturbance and erosion increments (Hough 1995), soil and air temperature (McDonnell et al. 1993), $\mathrm{CO}_{2}$ and $\mathrm{O}_{3}$ concentration (Sukopp 1998), precipitation likelihood (Botkin \& Beveridge 1997), as well as nutrient, pollutant, pesticide, and herbicide retention and storage (Pouyat \& McDonnell 1991). Future experimental research in this area should control for multiple factors associated with changes in soil and land use.

\section{Native species richness}

Elton (1958) suggested that species-rich communities should be the most resistant to biological invasions. Nevertheless, the study by Arroyo et al. (2000) in central Chile did not provide support for Elton's original hypothesis. This region harbors a lower number of exotic species as compared to California, despite having a lower species richness of native plants per surface area. However, Arroyo et al.'s results may be considered more indicative than robust, given that in drawing comparisons at such large biogeographical scales, it is difficult to have an adequate number of replicates (Stohlgren et al. 1999a), and the difference between the number of exotic species in both regions could also be strongly influenced by propagule pressure (Kolar \& Lodge 2001), that presumably is higher in California than in Chile.

In contrast, at the small scale of $1-\mathrm{m}^{2}$ to 400- $\mathrm{m}^{2}$ plots, Sax (2002a) concluded that, at least in the dry matorral on the coast of central Chile, the richness of exotic species was positively correlated with the diversity of native plants. This author suggested that both native and exotic species are responding similarly to environmental conditions and thus competition may not be operating, or not controlling local species richness (but see Byers \& Noonburg 2003). Several studies have suggested that the causes that explain the increase in exotic species richness should be similar to those factors involved in the increase of native species richness within the same communities (Pickard 1984, Rejmánek 1996, Wiser et al. 1998, Smith \& Knapp 1999). Specifically, disturbances and fluctuating resources in plant communities may facilitate the coexistence of native and exotic species (Davis et al. 2000, Sax et al. 2002).

Finally, Elton's original hypothesis has not been subjected to test at a regional scale in 
central Chile. The great variety of native and anthropogenic communities in the region could be an appropriate scenario for determining the effect of plant naturalizations on local and regional extinction rates of native plants.

\section{ATTRIBUTES OF NATURALIZED PLANTS}

Most studies of species invasions use a reductionist perspective in which the characteristics of exotic species are used to predict the success of invasion (Rejmánek 2000). This approach suggests that a successful invader can be characterized by a combination of traits, which would facilitate its spread into new receiving habitats (Baker 1974, Noble 1989, Reichard \& Hamilton 1997). The principal characteristics that have been considered to facilitate the invasion of an exotic plant are: the capacity of asexual reproduction (Panetta 1993, Reichard \& Hamilton 1997), the presence of perfect flowers, flowering period (Goodwin et al. 1999), small-sized genome (Rejmánek 1996), fast growth of the juvenile period (Aronson et al. 1992, Rejmánek \& Richardson 1996, Grotkopp et al. 2002), short generation time (Grotkopp et al. 2002), immediate and rapid germination in a wide range of physical conditions (Reichard \& Hamilton 1997), small seeds (Rejmánek \& Richardson 1996, Grotkopp et al. 2002), high competitive ability (Bakker \& Wilson 2001), together with ecophysiological adaptation to heterogeneous and stressful environments (Goodwin et al. 1999). Below, we address what is known regarding these traits among exotic species present in central Chile.

\section{Life-history traits}

Few studies suggest that a specific life history trait could have favored the invasion of exotic plant species in Chile. Montenegro et al. (1991), in a limited number of sites, found that the most frequent herbs in central Chile are those with annual life cycles. Recently, it was suggested that, because herbs with annual life cycles are poorly represented in the native flora of central Chile, available sites are more susceptible to the invasion of exotic plants that possess this life history trait (Holmgren et al. 2000a). However, Arroyo et al. (2000) rejected this hypothesis at a biogeographical scale. A comparison of exotic species with annual life cycles in central Chile and California, with the latter having a high representation of native annual species, showed that Chile is no more susceptible to annual species introduction than is California. Thus, high representation of annual species at a geographical scale is likely related to the high availability of annual species in the set of exotic flora that was introduced to central Chile from the start, and not necessarily to an advantage of exotic plants with annual life cycles over those exotics with perennial life cycles.

On the other hand, preliminary results of a comparative analysis of the traits of those species that have been introduced to Chile show that of 143 exotic species on which information is available, $95 \%$ possess hermaphroditic flowers, $3.5 \%$ of the taxa are monoecious, and $1.5 \%$ are dioecious. In addition, seed size, fruit shape, and seed dispersal mechanisms have been shown to be inconclusive traits regarding species invasiveness (Castro \& Figueroa unpublished data). However, these latter results should be interpreted with caution because the analysis did not compare between invasive and noninvasive naturalized species (see Rejmánek 1999).

\section{Competitive ability}

Experimental evidence on resource competition between exotic and native plants is scarce in Chile. In the matorral, Fuentes et al. (1986) proposed that native woody seedling establishment in exposed areas is very hard in part due to increased competition with grasses, which are mostly exotic species. Later, Holmgren et al. (2000a) in a matorral located on the foothills of the Andean Ranges showed that the erect annual native grass Bromus berterianus is competitively dominant over exotic prostrate annuals such as Erodium spp. because the former reduces the amount of photosynthetically active light reaching the soil surface. However, plant competitive ability could change if nutrient availability in the soil is limited. For example, exotic prostrate annuals are most successful in nutrient-poor soils because they allocate resources to develop a deeper root system than do native grasses and, in contrast, native grasses are significantly more abundant in high-fertility soil, which affords unlimited nutrients (Holmgren et al. 2000a). Recently, a study at a spatial scale < $400 \mathrm{~m}^{2}$ in a xeric matorral on the coast of central Chile, with relatively low cover of woody species, showed the existence of a significant negative correlation between herbaceous cover of native and exotic species, as well as the lack of a significant relationship 
between woody cover and herbaceous richness (Sax 2002a). Thus, at least for these communities in central Chile, it appears that competition for light and nutrients between native and exotic herbs may be operating and affecting their abundance, and that native woody species may be of minor importance in structuring these systems (Sax 2002a).

Regarding exotic tree plantations, large differences in species diversity and vegetational structure have been found between native forests and neighboring exotic Pseudotsuga menziesii plantations (Frank \& Finckh 1997). P. menziesii plantations are extremely poor in native plants, a pattern that was also described for plantations of the exotic Pinus radiata (von Buch \& Osorio 1987). Exotic $P$. menziesii and $P$. radiata displace native epiphytes and vines because of the monostratified structure of the plantations, which hold only tree and herbaceous cover (von Buch \& Osorio 1987, Frank \& Finckh 1997). However, these results should be interpreted with caution because the observed differences between forest plantations and native forests may be associated to forest management strategies and not to the competitive ability of the respective species (Sax 2002b).

Similarly, Atriplex canescens, A halimus and A. nummularia in the arid region of central Chile, cause a reduction in richness and cover of the herbaceous stratum by reducing the amount of light reaching the soil (Torres 1999). However, when these shrubs are pruned and managed, they can enhance herbaceous richness and vegetative cover due to a reduction in water stress by facilitating mist condensation, and contributing with an adequate concentration of organic matter in leaf litter (Lailhacar et al. $1989^{2}$, Lailhacar \& Torres 2002).

On the other hand, Matthei (1995) reported that an important number of exotic herbs have toxic compounds. However, no evidence exists that these toxins actually have negative effects on the survival or abundance of native or of exotic plants. Despite this, Atriplex nummularia, a species that was introduced from Australia, was shown to have allelopathic effects, inhibiting annual species in natural grasslands in arid northern Chile (Aliaga 1982). Further, phytotoxic chemicals that leach from

${ }^{2}$ LAILHACAR S, A CARRASCO, MA SADZAWKA \& G CASTELLARO (1989) Effet de l'arbuste fourrager Atriplex repanda Phil. sur fertilité du sol et sur la strate herbace é associée. XVI Congrès International de Herbages, Nice, France. the leaves and litter of Eucalyptus species can directly inhibit germination and delay seedling growth of grasses in North America (del Moral \& Muller 1970). But their effects are not known for native vegetation in Chile.

In sum, for mediterranean-type ecosystems of Chile,the available evidence suggests that competitive ability of naturalized plants may be important in determining invasiveness at a local scale.

\section{Ecophysiological tolerance}

The invasiveness of exotic species is associated with wide tolerances to requirements for germination (Reichard \& Hamilton 1997). In this respect, investigations on Chilean mediterranean-type ecosystems are scarce and have been carried out mainly with managed invasive annuals. For instance, most invasive annuals that are used for the management of grasslands in central Chile (e.g., Avena barbata, Hordeum murinum, Vulpia bromoides) are able to germinate under a wide range of temperatures (Johnston et al. 1989, 1994, Olivares et al. 1990), and it is known that the germination of Erodium invasive species is highly tolerant to cold and dry conditions (Olivares et al. 1999). For example, the germination in Erodium species starts at $1{ }^{\circ} \mathrm{C}$ when water availability is high. Similarly, Vidiella \& Armesto (1989) and Gutiérrez (1993) recorded in xeric environments of northcentral Chile that naturalized ephemerals have greater tolerance to water stress than germinating native ephemerals, which in part may explain the persistence of naturalized annuals in those environments.

Regarding seed dormancy, it is known that the response of naturalized plants in central Chile is diverse (Figueroa \& Jaksic 2004). The major naturalized species in central Chile show physiological dormancy that can be broken by chilling (e.g., Chenopodium album, Plantago lanceolata) and elevated temperature (e.g., Avena fatua, Poa annua, Stellaria media). A less numerous group of naturalized annuals shows physical dormancy (e.g., Erodium spp, Ipomoea purpurea). However, the number of naturalized species that does not show dormancy at the time of seed dispersal (e.g., Cardus nutans, Vulpia bromoides) is not negligible. On the other hand, published results indicate that the naturalized annuals in central Chile can germinate on a wide temperature range, and that they are highly resistant to cold and dry conditions (Figueroa \& Jaksic 2004). 
There are few experimental studies on growth and ecophysiology of naturalized plants in central Chile. Most have focused on unnaturalized woody exotic (Ovalle et al. 1996, Arredondo et al. 1998, Aronson et al. 2002) and annual herbs used in productive prairies (e.g., Lailhacar \& Aylwin 1988, Torres 1999, Del Pozo et al. 2002a,b). For example, invasive annual herbs are highly tolerant to soils with low nutrient concentrations (Squeo et al. 1994, Holmgren et al. 2000a) but have low tolerances to shading (Lailhacar et al. 19991', Torres 1999). Even Medicago polymorpha, which was successfully introduced from Europe, recruits on a wide variety of regions, soils, and habitats of Chile (Rihan 1988 in Del Pozo et al. 2002a,b). The vegetative growth of this species increases with increasing precipitation (Lailhacar et al. 1999'1), temperature (Del Pozo et al. 2002b), soil surface pH (Torres 1999) and, contrary to many invasive species in Chile, has a high tolerance to shading (Lailhacar \& Aylwin 1988, Torres 1999). Also, for Malvia nicaensis it has been shown that growth increases in soils with high Nitrogen content (Lailhacar \& Aylwin 1988, Torres 1999).

In sum, the few available data for Chilean mediterranean-type ecosystems suggest that in general naturalized annuals are tolerant to growing in poor soil conditions but have a low tolerance to shading. However, the naturalized annual $M$. sativa stands as a remarkable exception, that additionally shows a significant ecotypic differentiation in phenology and winter "vigor", along environmental gradients in central Chile (Del Pozo et al. 2000, 2002a,b).

\section{HISTORICAL PROCESSES}

In addition to the drivers identified in Fig. 1, history seems to play a significant role in the introduction success and spread of exotic species because it is possible that priority effects (e.g., Drake et al. 1993) or microevolutionary changes leading to increased invasiveness may be operating. In this context, the history of the invasion process could be of paramount importance for understanding current and future trends in species invasions. Below we provide a summary of the history of plant invasions in Chile and show that widespread exotic species were introduced earlier than more localized species.

\section{Record of arrival of exotic plants}

The Spanish conquest of Chile in the $16^{\text {th }}$ century marked the first deliberate introductions of several Old World plant and animal species into central Chile (Montenegro et al. 1991, Jaksic 1998). However, the first scientific descriptions and collections of the Chilean flora date from the $18^{\text {th }}$ century, and were carried out by naturalists interested in the description of the native flora, not on the introduced elements. The emphasis on the discovery of native plants with agricultural and medicinal uses prevailed as the criterion of collection in the expeditions led by Louis E. Feuillée between 1708 and 1710 (Philippi 1867) and those of Hipólito Ruiz and José A. Pavón between 1782 and 1783 (Ruiz \& Pavón 1798-1802). It is estimated that towards the end of the $18^{\text {th }}$ century, numerous exotic plants were already naturalized in Chile, as is the case of Cardamine hirsuta, Medicago polymorpha, Spartium junceum and Bromus hordeaceus (Castro unpublished data).

More systematic efforts to expand knowledge on the diversity of plants started with the arrival of the French naturalist Claudio Gay in 1828 (Reiche 1901, Muñoz-Schick 1991). Gay (1845-1854) performed a complete floristic inventory of Chile as part of his "Physical and political history of Chile," which included 146 naturalized plants. Philippi (1875) reported the presence of 180 naturalized plants, which he classified into four groups: (1) Marine coastal plants (e.g., Cotula coronopifolia); (2) aquatic or freshwater plants (e.g., Rorippa nasturtium-aquaticum, Callitriche terrestris); (3) accidentally introduced weeds (e.g., Fumaria media, Sisymbrium officinale, Erodium cicutarium, E. moschatum, E. malacoides, E. botrys); and (4) naturalized cultivated plants (e.g., Ranunculus repens, Brassica nigra, Mentha piperita, Holcus lanatus).

At the turn of the $20^{\text {th }}$ century, Karl Reiche (1896-1911) published "Flora of Chile," incorporating numerous plants that were naturalized in central Chile, such as Cotula australis, Chrysanthemum segetum and Lactuca serriola. Later, Baeza $(1928)^{3}$ became one of the first botanists in Chile to show a special interest for naturalized species (which he referred to as invasive species). This author called attention to the growing importance of the naturalized flora in the country. In addition, Espinosa (1929) documented the presence of Linaria vulgaris, Agrostemma githago, Hypericum perforatum, Arctium minus, Cirsium

\footnotetext{
${ }^{3}$ BAEZA VM (1928) Contribución al conocimiento de la flora advena de Chile: Apuntes Docentes. Instituto Pedagógico, Universidad de Chile, Santiago, Chile. 33 pp.
} 


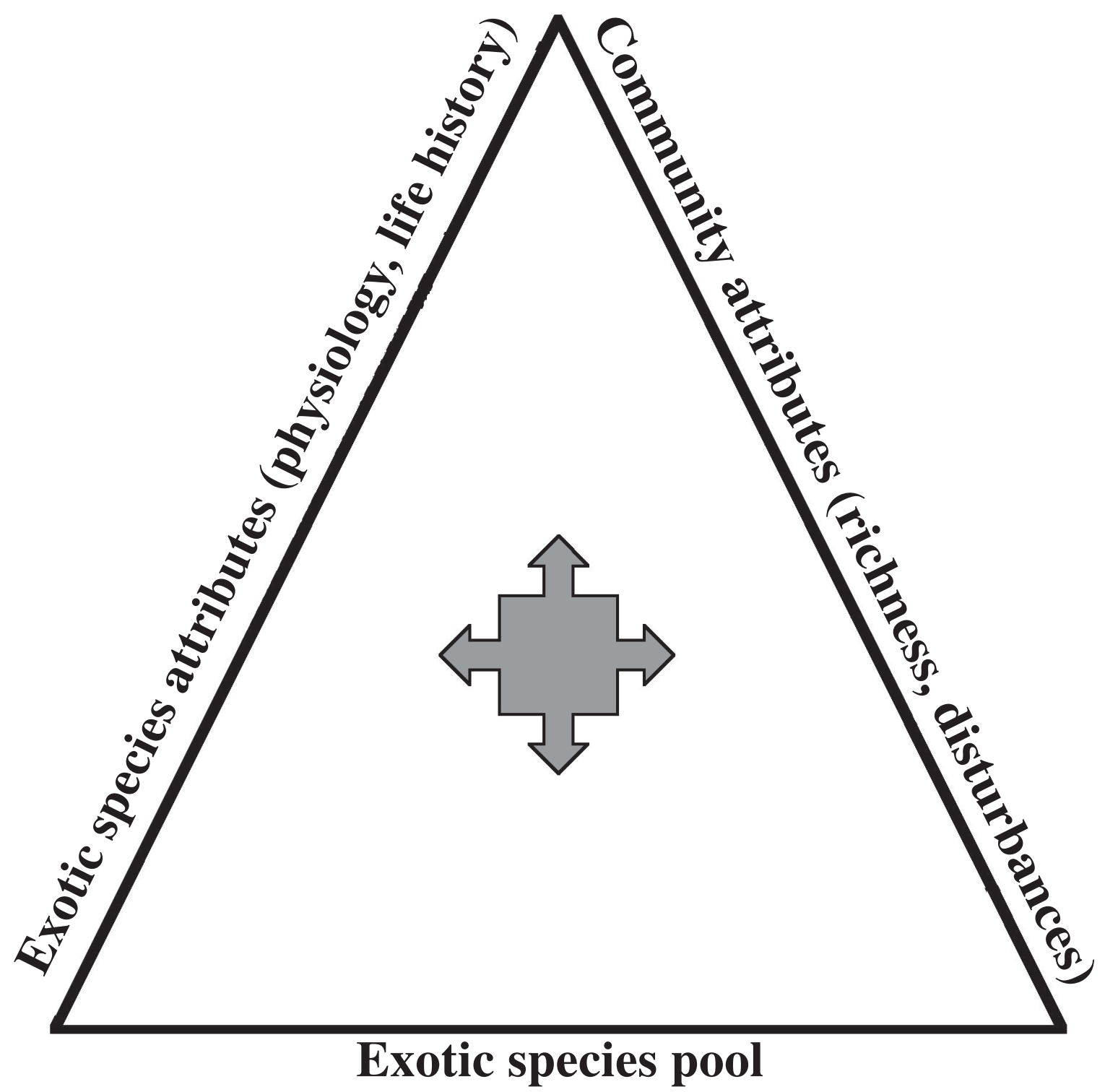

Fig. 1: Representation of interactions among three general causes of exotic plant invasions. The exotic species pool is determined by exotic plant availability established above the ground and in the seed bank of the soil. The native community attributes are represented by plant richness and disturbance regime. Finally, species attributes determine exotic plant traits associated with their successful naturalization and further spread.

Representación de las interacciones entre tres causas generales de la invasión de plantas exóticas. El conjunto de especies exóticas es definido por la disponibilidad de plantas exóticas en la vegetación y en el banco de semillas del suelo. Los atributos de la comunidad nativa están representados por la riqueza de plantas y el régimen de perturbaciones. Finalmente, los atributos de las especies quedan definidos por los rasgos de las plantas exóticas asociados con su naturalización exitosa y posterior expansión. 
arvense and Pulchea absinthioides, as weeds in cultivated lands in the central zone of Chile.

Later, Gunckel (1935) recorded the naturalization of Lupinus arboreus and Teline monspessulana, two Papilionaceae species initially cultivated in the Botanical Garden at Santiago and which then spread throughout central Chile. Garaventa (1937) recognized Rubus ulmifolius, Acacia dealbata, A. melanoaxylon, Nicotiana glauca and Salix babilonica as exotic plants that colonized bare ground. Further, Drathen (1937) mentioned Rubus ulmifolius and Ulex europaeus as species capable of excluding Alstroemeria aurantiaca from established sites. Acevedo (1939) catalogued 13 species as exotic grasses in Chile (e.g., Agrostis verticillata, Bromus rigidus, Paspalum urvillei, Festuca megalura), indicating sites of collection, and accessioning them in the Herbarium of the Museo Nacional de Historia Natural (MuñozSchick et al. 1981). Navas (1973, 1976, 1979) undertook a complete floristic study of Santiago's basin, considering 21 collection sites situated in a $100 \times 40 \mathrm{~km}$ area, between $33^{\circ} 12^{\prime}$ and $33^{\circ} 56^{\prime} \mathrm{S}$. She recorded a naturalized flora of 60 species among 229 native species, but these figures should be revised in light of subsequent changes in nomenclature.

The most recent and complete registry of the vascular flora of Chile is the "Catálogo de la Flora Vascular de Chile" (Marticorena \& Quezada 1985, 1987). A flora composed of 6,058 taxa including subspecies are catalogued here, of which 582 correspond to naturalized species. More recently, Matthei (1995) recorded 690 exotic plant species that grow as weeds in croplands, causing important economic damages in productive lands. Using Matthei (1995) as their principal source of information, together with the data base of the Chilean flora and some local floristic studies (Henríquez et al. 1995, Marticorena et al. 1998), Arroyo et al. (2000) provided a catalogue of 707 naturalized plant species $(12 \%$ of the total Chilean flora). According to Matthei (1995) and Arroyo et al. (2000), the central regions of Chile hold close to $60 \%$ of the naturalized flora, thus constituting one of the most invaded areas of the country. In central Chile, the number of naturalized species represents approximately $18 \%$ of the flora that has been described for this region (Arroyo \& Cavieres 1997).

In summary, the first exotic species were intentionally introduced into the country, and it seems that they have spread completely uncontrolled. Thus, the proportion of exotic plants in the total flora of Chile will likely increase with more monitoring efforts.

\section{Biogeographic origin of exotic plants}

With respect to the origin of the exotic species in central Chile, ca. $70 \%$ came from Eurasian and northern parts of Africa (Arroyo et al. 2000). Another important source of exotic plant species is the rest of South and North America, especially from the subtropical regions, which in total contribute $12 \%$ of the exotic flora. Tropical regions contribute $8.7 \%$, while other sources such as South Africa, temperate regions of the Northern Hemisphere, and Australasia, have each contributed less than $2.5 \%$ of the exotic flora in central Chile. The high proportion of Eurasian-origin flora is remarkable (Fig. 2). This major biogeographical feature of the introduced flora of central Chile is concordant with the flora introduced to all regions of mediterranean climate in the world (Groves 1991), but is not necessarily concordant with others climatic regions (Guillerm 1992). The higher percentage of Eurasian species in the exotic flora of central Chile may be due to several attributes: (1) Eurasian species posses traits associated to invasiveness, which allowed them to quickly spread in mediterranean-type ecosystems in Chile during the last 450 years, (2) the historical use of land in central Chile may have allowed for a higher invasibility of local communities, and (3) in central Chile, Eurasian plants presented higher arrival rates and larger species-pool than plants of other origins, thus native communities have been in contact with a higher number of Eurasian exotics. This interesting problem will be dealt with in the following section.

\section{Propagation and spread exotic plants}

In the beginning, the introduction of exotic plants was promoted enthusiastically by diverse governmental agencies. Exotic plants were imported through exchange programs with European institutions with the purpose of using them in teaching, botanical medicine, and in the search for new crop plants (Philippi 1881). Toward this aim, the grounds of the Quinta Normal de Agricultura, were set aside for teaching and research in agriculture, and used as a testing site. This way, numerous introduced plants were cultivated for their study and propagation (Mostny-Glaser \& Niemeyer-Fernández 1983). Philippi (1881, 


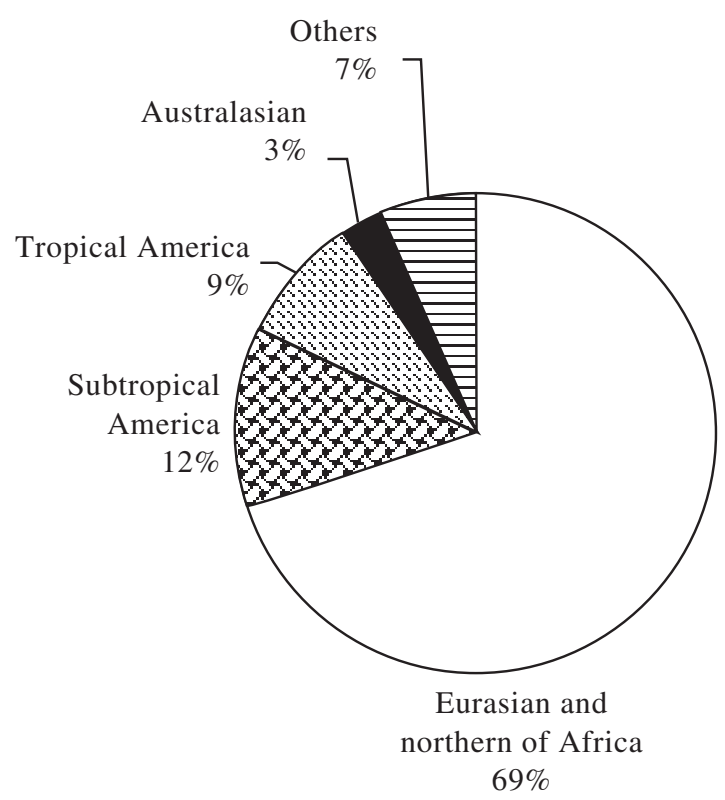

Fig. 2: Biogeographic origin of the exotic plant species in central Chile. Percentages of each origin are shown.

Origen biogeográficos de las especies de plantas exóticas en Chile central. Se muestran los porcentajes de cada origen.

1884) catalogued approximately 2000 exotic plants that were being cultivated in the botanical gardens of the Quinta Normal de Agricultura, although in time it came to hold more than 3,000 species (Marticorena \& Rodríguez 1995). A total of 43 species apparently "escaped" accidentally from this cultivation site, among them Eschscholzia californica, Veronica verna and Centaurea jacea, which are now naturalized and widely distributed in central Chile (Matthei 1995).

On the other hand, the exact date of introduction as well as the number of introduction events are difficult to establish, given that many naturalized species have been introduced involuntarily in the country (Arroyo et al. 1995). Nevertheless, from 1854 onwards, a sustained increment occurred in the number of exotic plants introduced to Chile, resulting in an annual rate of 2-3 new naturalized species (Matthei 1995), which is lower than the figures (four to six species per year) computed for other mediterranean-type ecosystem (Groves 1991). Using the date in which each exotic species was first recorded and/or collected in continental Chile, Arroyo et al. (2000) found that the date of introduction is related with the degree of distribution of the species throughout the country. Recently, Castro et al. (20034) showed that the extent of the geographic distribution of naturalized species in Chile increases with time since introduction into the country (Fig. 3), demonstrating that arrival time of propagules is of great relevance to understand the present-day spread of exotic plants (see also Pysek et al. 2003), independently of their biogeographic origin. The exotic flora of European origin has been exposed, for a long time, to a selective environment of anthropogenic thrust. Di Castri (1989) proposed that this European species pool is highly invasive, because it has evolved in response to drastic climatic and other environmental changes, including intensive agriculture. Castro et al. $\left(2003^{4}\right)$ postulated that this hypothesis is not supported in Chile, because the exotic flora here originated from different regions and does not show differences in their regional spread within the country. Thus, an alternative explanation for the ample spread of Eurasian flora in mediterranean regions, and in Chile in particular, may be associated to the high historical availability of plants of this origin, due to an asymmetrical exchange in imports and exports to and from that region (Castro et al. 20034).

\section{ECOSYSTEM IMPACT OF INVASIVE PLANTS IN CENTRAL CHILE}

Plant naturalization may alter ecosystems in central Chile. An important ecosystem process that could be altered by exotic legumes is the nitrogen fixation rate. Although published information does not exist for central Chile, the nitrogen-fixing annual legumes Medicago polymorpha (Del Pozo et al. 2000), Trifolium spp. and the shrubs Cytisus scoparius and Ulex europaeus may alter the abundance and distribution of the native flora by enhancing the nitrogen contents of the soil. Ulex europaeus, which was introduced to Chile during the $19^{\text {th }}$ century (Philippi 1875), is a species that inhibits the regeneration of woody species in disturbed native forests. In contrast, Carduus nutans, a species native from central Chile, was shown to inhibit nitrogen fixation by the legume Trifolium

\footnotetext{
${ }^{4}$ CASTRO SA, FIGUEROA JA, MUÑOZ-SCHICK M \& JAKSIC FM. 2003. Importancia de la fecha de introducción como determinante de la distribución geográfica de plantas naturalizadas en Chile continental. XLVI Reunión Anual de la Sociedad de Biología de Chile. XII Reunión Anual de la Sociedad de Ecología de Chile, Puyehue. Biological Research 38: R-21.
} 


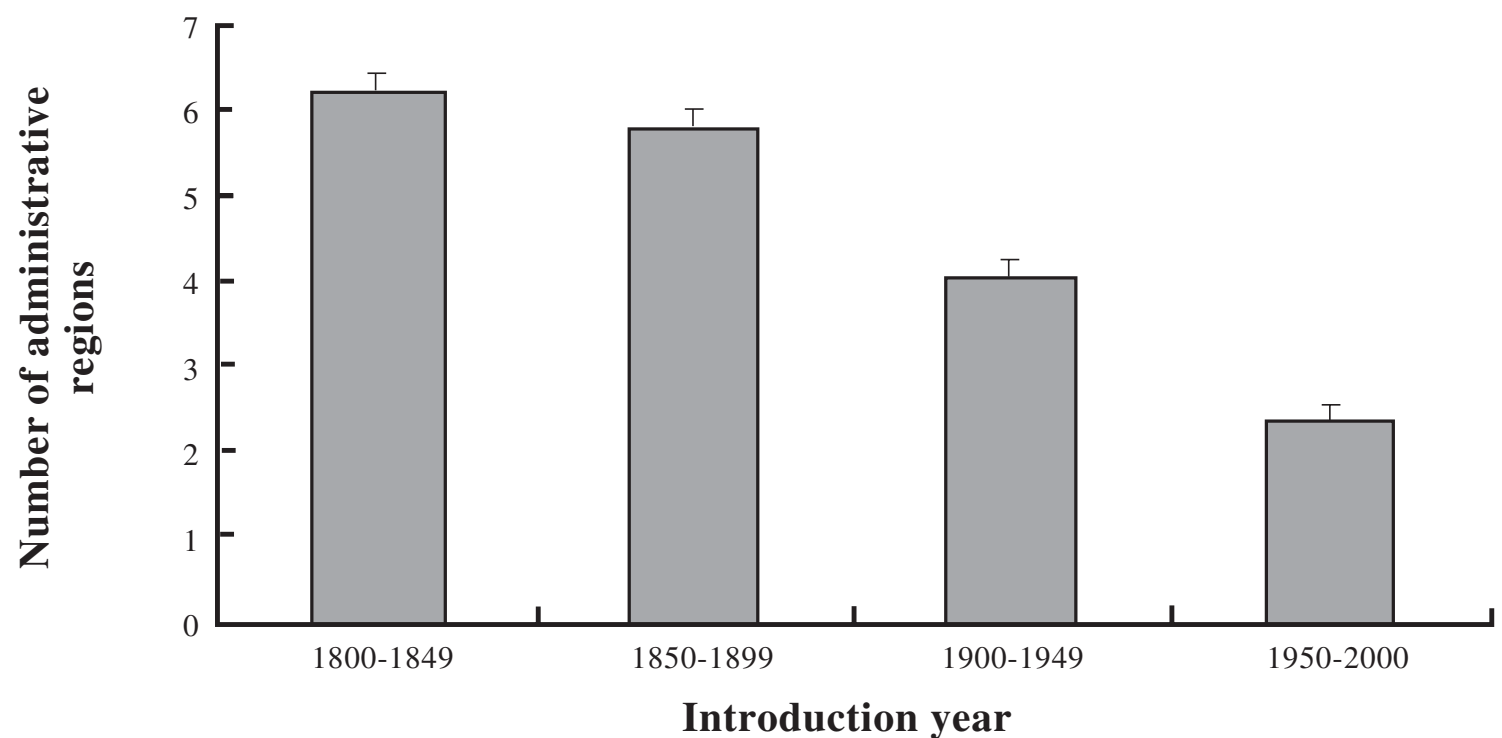

Fig. 3: Mean number of administrative regions occupied by naturalized plants in Chile according to the introduction year of 428 species (bars represent \pm SD). ANOVA shows a significant difference among years $\left(\mathrm{F}_{1,3}=12.1 ; \mathrm{P}<0.001\right)$.

Media aritmética de regiones administrativas que son ocupadas por plantas naturalizadas en Chile, de acuerdo al año de introducción de 428 especies (las barras representan \pm DE). ANDEVA muestra una diferencia significativa entre años $\left(\mathrm{F}_{1,3}=12,1 ; \mathrm{P}<0,001\right)$.

repens in Australia (Wardle et al. 1994). However, no studies have been conducted for determine if similar effects of $C$. nutans occur among native legumes of central Chile.

Evidence also exists of naturalized species altering other ecosystem-level processes, such as the rate of methane release in wetlands (e.g., Lythyrum salicaria), soil chemistry, and nutrient cycling in forests (e.g., Pseudotsuga menziesii) (Frank \& Finckh 1997), and modifications of the water cycle by changes of evapotranspiration rates (Kremer \& Running 1996). In this respect, annual exotics such as Avena spp., Bromus spp. and Vulpia spp., which have replaced native perennials species in mediterranean-type ecosystems in Chile, use less of the deep-water reserves, because they have shallower roots. As a consequence, these species may have produced a significant decrease in evapotranspiration in the matorral of central Chile. On the other hand, exotic forest plantations may have altered the hydrology (Canadell et al. 1996), annual evapotranspiration, and microclimate (Kremer \& Running 1996) in large areas of the Coastal Range of central Chile (Lara \& Veblen 1993).

There are species that could alter the frequency and rates of disturbances in central Chile. For instance, Senecio mikanoides, a species naturalized in Chile that in California forms dikes that contain the flow of water decomposing organic matter; Cynodon dactylon, which in Arizona stabilizes the sediments in streams, and Arundo donax, which on the coast of California enhances the deposition of sediments in rivers (see Dukes \& Mooney in this special issue). Additionally, the replacement of native forests by exotic forest plantations may have altered the frequency of fires in the last 40 years (Montenegro et al. 2002). Here, exotic plantations deserve a specific mention, because Chile holds the most extensive Pinus radiata plantations of the entire world (Lewis and Ferguson 1993). Approximately two million hectares are occupied by species of Pinus spp. and Eucalyptus spp., constituting a serious threat for the maintenance of native biodiversity (Armesto et al. 1998) and thus likely candidates for strong ecosystem disruptions. These species were introduced for commercial purposes, and thus may not be considered as naturalized (Arroyo et al. 2000) or invasive (Kruger et al. 1989). However, these plantations should be studied, specially considering that the trees involved are likely altering large-scale spatial and temporal processes that native ecosystems had never experienced before (Armesto et al. 
1998). Additionally, there is evidence of Pinus radiata reproducing and regenerating in native forest fragments (Bustamante et al. 2003).

\section{CONCLUSIONS}

Despite the fact that species naturalizations in central Chile are cause of concern because of their widespread occurrence and large species numbers, there are important gaps in our knowledge of this phenomenon in Chile (Vázquez \& Aragón 2002). In the last few years, the priority has been to determine regional patterns of naturalized plants and availability at regional (Arroyo et al. 2000, Castro et al. 2003 ${ }^{4}$ and landscape scales (Pauchard \& Alaback 2004), taxonomic and systematic characteristics of introduced species (Matthei 1995), ecosystem regulation models of vegetation (Holmgren 2002), and microscalelevel patterns (Sax 2002a). Better understanding of plant naturalizations could be reached by filling important gaps on the three major drivers of invasion (Fig.1), specially on the historical processes and the ecosystem impacts of exotic species.

For instance, in relation to the current availability of naturalized species in central Chile, which reaches up to $50 \%$ of total flora in evergreen matorral and Acacia espinal, it is important to answer the following unresolved questions. Is it possible to decrease the size of the exotic propagule pool to decrease invasion likelihood in the most susceptible communities? Is it possible to calculate the naturalization rate assuming that we know the approximate availability of exotic plants from exogenous sources? In sum, Is the temporal and spatial pattern of exotic plant naturalization determined and predictable by exotic propagule availability?

On the other hand, studies on the local communities and habitats invaded in Chile have intensified during the last few years (Holmgren et al. 2000a, Arroyo et al. 2000, Pauchard \& Alaback 2004). However, further large-scale studies are urgently required in order to provide valuable information to improve the present network of protected areas, and to identify sites of high priority for the conservation of native biodiversity, which is threatened by exotic species (Pauchard \& Alaback 2004). Concepts developed in the field of landscape ecology are tools that have been used successfully in the development of an ecological theory of plant invasions (Rejmánek 1999). Also, metapopulation concepts and models could be of great utility for explaining the persistence, at the local and landscape scales, of abundant and rare exotic populations or the susceptibility of disturbed local habitats to increased propagule availability and immigration of exotics (Marquet 2002).

With regard to species traits linked to invasiveness, this is one of the invasion phenomena less well developed in Chile. In fact, it has practically been ignored, with the exception of the reportedly annual life history of herbs. Further, genetic molecular tools could be of great utility for determining rates of mutation, population genetic variability, and rates of dispersal (Novak \& Mack 2001, Sakai et al. 2001).

Interestingly, historical analyses of the presence of exotic plants could help explain many of the present-day regional distributional patterns of the naturalized flora in central Chile (Castro et al. 2003 ${ }^{4}$ ). In the same way, questions of similar concern are still unresolved. Can we say anything about the future spread of recently naturalized species, using our knowledge of the naturalization history of exotic species? In short, How predictable is the process of invasion by exotic plants?

Finally, perhaps one of the areas that has provided the best theoretical and practical results with direct application to the management of undesired species, has been the identification of key invading species that alter ecosystem-level processes and mechanisms (Glyphis et al. 1981, Wheeler et al. 1987, Vitousek \& Walker 1989, Gordon 1998, D'Antonio et al. 2001, Dukes \& Mooney this special issue). However, we know very little about the impacts that widespread naturalized plants in Chile (e.g., Erodium spp., Ulex europaeus, Pinus radiata) have on ecosystem function. This represents an open and urgent area for research of plant invasions in the country.

The study of plant invasions is relevant in the fields of conservation biology, resource management, global change, and ecological, ecosystem, and evolutionary theory (Hobbs 2000, Mack et al. 2000, Rejmánek 2000, Sakai et al. 2001, Pysek et al. 2003). Notwithstanding recent advances, the systematic study of plant invasions in Chile lags far behind what it should be (Vázquez \& Aragón 2002). We call for an allout effort to understand the impacts of invasive exotic species in Chilean ecosystems.

\section{ACKNOWLEDGMENTS}

We thanks A. Pauchard and four anonymous reviewers whose comments on this article 
improved it substantially. This study was funded by Fondecyt-Fondap 1501-0001. J.A Figueroa is supported by grants from the AW Mellon Foundation and the Center for Advanced Studies in Ecology \& Biodiversity, Pontificia Universidad Católica de Chile. SA Castro is supported by grants from the AW Mellon Foundation. This is a contribution to research program of Fundación Entorno.

\section{LITERATURE CITED}

ACEVEDO R (1939) Algunas gramíneas exóticas naturalizadas en Chile. Revista Chilena de Historia Natural 43: $80-83$.

ALIAGA C (1982) Fitotoxicidad de lixiviados de hojas de los arbustos Atriplex nummularia y Atriplex repanda sobre especies terófitas de la pradera natural. Tesis Ingeniero Agrónomo. Facultad de Ciencias Agrarias y Forestales, Universidad de Chile, Santiago, Chile. 91 pp.

ARMESTO JJ, R ROZZI, C SMITH-RAMÍREZ \& MKT ARROYO (1998) Conservation targets in South American temperate forests. Science 279: 12711272.

ARONSON J, C OVALLE \& J AVENDAÑO (1992) Early growth rate and nitrogen fixation potential in fortyfour legume species grown in an acid and a neutral soil from central Chile. Forest Ecology and Management 47: 225-244.

ARONSON J, A DEL POZO, C OVALLE, J AVENDAÑO, A LAVÍN \& M ETIENNE (1998) Land use changes and conflicts in central Chile. In: Rundel PW, G Montenegro \& FM Jaksic (eds) Landscape degradation and biodiversity in mediterranean-type ecosystems: 155-168. SpringerVerlag, Berlin, Germany.

ARONSON J, C OVALLE, J AVENDANO, L LONGERI \& A DEL POZO (2002) Agroforestry tree selection in central Chile: biological nitrogen fixation and early plant growth in six dryland species. Agroforestry Systems 56: 155-166.

ARREDONDO S, J ARONSON, C OVALLE, A DEL POZO \& J AVENDAÑO (1998) Screening multipurpose legume trees in central Chile. Forest Ecology and Management 109: 221-229.

ARROYO MTK, L CAVIERES, C MARTICORENA \& M MUÑOZ-SCHICK (1995) Convergence in the Mediterranean floras in central Chile and California: insights from comparative biogeography. In: Arroyo MTK, PH Zedler \& MD Fox (eds) Ecology and Biogeography of Mediterranean Ecosystems in Chile, California, and Australia: 43-88. Springer-Verlag, New York, New York, USA.

ARROYO MTK \& L CAVIERES (1997) The mediterranean type-climate flora of Central Chile. What do we know and how can we assure its protection? Noticiero de Biología (Chile) 5: 48-56.

ARROYO MTK, JR ROZZI, JA SIMONETTI, JA MARQUET \& M SALABERRY (1999) Central Chile. In: Gil PR, C Goettsch Mittermeier \& R Mittermeier (eds) Hotspots: earth's biologically wealthiest and most threatened ecosystems: 161171. CEMEX, México Distrito Federal.

ARROYO MTK, C MARTICORENA, O MATTHEI \& L CAVIERES (2000) Plant invasions in Chile: present patterns and future predictions. In: Mooney HA \& RJ Hobbs (eds) Invasive species in a changing world: 385-421. Island Press, Covelo, California, USA.

ÁVILA G, ME ALJARO \& B SILVA (1981) Observaciones en el estrato herbáceo del matorral después del fuego. Anales del Museo de Historia Natural de Valparaíso (Chile) 14: 99-105.

BAKER HG (1974) The evolution of weeds. Annual Review of Ecology and Systematics 5: 1-24.

BAKKER J \& S WILSON (2001) Competitive abilities of introduced and native grasses. Plant Ecology 157: 117-125.

BOTKIN DB \& CE BEVERIDGE (1997) Cities as environments. Urban Ecosystems 1: 3-19.

BRIGHT C (1996) Understandig the threat of bioinvasions. In: Brown LR, JN Abramovitz, C Bright, C Flavin, G Gardner, H Kane, A Platt, S Postel, D Roodman, A Sachs \& L Starke (eds). State of the World 1996: 95-113. WW Norton, New York, New York, USA.

BYERS JE \& NOONBURG EG (2003). Scale dependent effects of biotic resistance to biological invasion. Ecology 84: 1428-1433.

BUSTAMANTE RO, IA SEREY \& STA PICKETT (2003) Forest fragmentation, plant regeneration and invasion processes across edges in central Chile. In: Bradshaw GA \& PA Marquet (eds) How landscapes change: 145-160. Springer-Verlag, Berlin, Heidelberg, Germany.

CANADELL J, RB JACKSON, JR EHLERINGER, HA MOONEY, OE SALA \& ED SCHULZE (1996) Maximum rooting depth of vegetation types at the global scale. Oecologia 108: 583-594.

CORPORACIÓN NACIONAL FORESTAL (CONAF) (1998) Impacto del fuego sobre el medio ambiente. Unidad de Gestión Manejo del Fuego: 1-16. Santiago. Chile.

COWLING RM, PM RUNDEL, BB LAMONT, MT KALIN-ARROYO \& M ARIANOUTSOU (1996) Plant diversity in mediterranean-climate regions. Trends in Ecology and Evolution 11: 362-366.

D'ANTONIO CM \& PM VITOUSEK (1992) Biological invasions by exotic grasses, the grass/fire cycle, and global change. Annual Review of Ecology and Systematics 23: 63-87.

D'ANTONIO CM, RF HUGHES \& PM VITOUSEK (2001) Factors influencing dynamics of two invasive $\mathrm{C}_{4}$ grasses in seassonally dry Hawaiian woodlands. Ecology 82: 89-104.

D'ANTONIO CM (2000) Fire, plant invasions, and global changes. Mooney HA \& RJ Hobbs (eds) Invasive species in a changing world: 65-93. Island Press, Covelo, California.

DAVIS MA, JP GRIME \& K THOMPSON (2000) Fluctuating resources in plants communities: a general theory of invasibility. Journal of Ecology 88: 528-534.

DARWIN C (1872) The origin of species by means of natural selection. The New American Library, New York, New York, USA. 478 pp.

DEL MORAL R \& CH MULLER (1970) The allelopathic effects of Eucalyptus camaldulensis. American Midland Naturalist 83: 254-282.

DEL POZO A, C OVALLE, J ARONSON \& J AVENDAÑO (2000) Developmental responses to temperature and photoperiod in ecotypes of Medicago polymorpha L. collected along an environmental gradient in central Chile. Annals of Botany 85: 809-814.

DEL POZO A, C OVALLE, J ARONSON \& J AVENDAÑO (2002a) Ecotypic differentiation in 
Medicago polymorpha L. along an environmental gradient in central Chile. I. Phenology, biomass production and reproductive patterns. Plant Ecology 159: 119-130.

DEL POZO A, C OVALLE, J ARONSON \& J AVENDAÑO (2002b) Ecotypic differentiation in Medicago polymorpha L. along an environmental gradient in central Chile. II. Winter growth as related to phenology and temperature regime. Plant Ecology 160: 53-59.

DI CASTRI F \& E HAJEK (1976) Bioclimatología de Chile. Vicerrectoría Académica, Pontificia Universidad Católica de Chile, Santiago, Chile. 128 pp.

DI CASTRI F (1989) History of biological invasions with special emphasis on the Old World. In: Drake JA, F di Castri, RH Groves, FJ Kruger, HA Mooney, M Rejmánek \& MH Williams (eds) Biological Invasions: a global perspective: 1-30. John Wiley \& Sons, New York, New York, USA.

DRAKE JA, TE FLUM, GJ WITTEMAN, T VOSKUIL, AM HOYLMAN, C CRESON, DA KENNY, GR HUXEL, CS LARUE \& JR DUNCAN (1993) The construction and assembly of an ecological landscape. Journal of Animal Ecology 62: 117-130.

DRATHEN T (1937) Maleza del antiguo continente. Revista Universitaria (Chile) 22: 221-223.

DRAYTON B \& RB PRIMACK (1996) Plant species lost in a isolated conservation area in metropolitan Boston from 1894 to 1993. Conservation Biology 10: 30-39.

DUKES JS \& HA MOONEY (2004) Biological invaders disrupt ecosystem processes in western North America. Revista Chilena de Historia Natural (in this special issue).

ELTON CS (1958) The ecology of invasions by animals and plants. Methuen, London, United Kingdom. 181 $\mathrm{pp}$

ESPINOSA M (1929) Algunas plantas que conviene evitar en los cultivos. Revista Chilena de Historia Natural 33: 233-236.

FRANK D \& M FINCKH (1997) Impactos de las plantaciones de pino oregón sobre la vegetación y el suelo en la zona centro-sur de Chile. Revista Chilena de Historia Natural 70: 191-211.

FIGUEROA JA \& FM JAKSIC (2004) Latencia y banco de semillas en plantas de la región mediterránea de Chile central. Revista Chilena de Historia natural 77: 201-215.

FIGUEROA JA, S TEILLIER \& FM JAKSIC (in press) Composition, size and dynamics of the seed bank in a mediterranean shrubland of Chile. Austral Ecology.

FUENTES ER, FM JAKSIC \& JA SIMONETTI (1983) European rabbits versus native rodents in Chile: effects on shrub seedlings. Oecologia 58: 411-414.

FUENTES ER, AJ HOFFMANN, A POIANI \& MC ALLIENDE (1986) Vegetation change in large clearings: patterns in the Chilean matorral. Oecologia 68: 358-366.

GARAVENTA A (1937) Plantas repobladoras y plantas invasoras de Chile central. Revista Universitaria (Chile) 22: 67-70.

GAY C (1845-1854) Historia física y política de Chile según documentos adquiridos en esta república durante doce años de residencia en ella y publicada bajo los auspicios del Supremo Gobierno. Botánica (Flora chilena). Santiago, Chile. 493, 532, 245, 453, 435, 159 pp.

GLYPHIS JP, SJ MILTON \& WR SIEGFRIED (1981) Dispersal of Acacia cyclops by birds. Oecologia 48: 138-141.
GOODWIN BJ, AJ McALLISTER \& L FAHRIG (1999) Predicting invasiveness of plant species based on biological information. Conservation Biology 13: 422-426.

GORDON DR (1998) Effects of invasive, non-indigenous plant species on ecosystem processes: lessons from Florida. Ecological Applications 8: 975-989.

GROVES RH (1991) The biogeography of mediterranean plant invasions. In: Groves RH \& F di Castri (eds) Biogeography of mediterranean invasions: 427-438. Cambridge University Press, Cambridge, United Kingdom.

GROTKOOP E, M REJMÁNEK \& T ROST (2002) Toward a causal expanation of plant invasiveness: seedling growth and life-history strategies of 29 pine (Pinus) species. American Naturalist 159: 396-419.

GUILLERM JL (1992) Weed invasion in agricultural areas. In: Groves RH \& F di Castri (eds) Biogeography of mediterranean invasions: 379-392. Cambridge University Press, Cambridge, United Kingdom.

GUTIÉRREZ JR (1993) The effect of water, nitrogen, and human-induced desertification on the structure of ephemeral plant communities in the Chilean coastal desert. Revista Chilena de Historia Natural 66: 337 344.

GUTIÉRREZ JR, G ARANCIO \& FM JAKSIC (2000) Variation in vegetation and seed bank in a Chilean semi-arid community affected by ENSO 1997. Journal of Vegetation Science 11: 641-648.

GUTIÉRREZ JR \& P MESERVE (2003) El Niño effects on the soil seed bank dynamics in north-central Chile. Oecologia 134: 511-517.

GUNCKEL H (1935) Dos leguminosas adventicias de la flora chilena. Revista Chilena de Historia Natural 39: 79-82.

HENRÍQUEZ JM, E PISANO \& C MARTICORENA (1995) Catálogo de la flora vascular de Magallanes (XII Region), Chile. Anales del Instituto de la Patagonia (Chile) 23: 5-30.

HOBBS RJ (2000) Land use change and invasions. In: Mooney HA \& RJ Hobbs (eds) Invasive species in a changing world: 385-421. Island Press, Covelo, California, USA

HOLMES PM \& RM COWLING (1997) Diversity, composition and guild structure relationships between soil-stored seed banks and mature vegetation in alien plant-invaded South African fynbos shrublands. Plant Ecology 133: 107-122.

HOLMGREN M, R AVILÉS, L SIERRALTA, A SEGURA \& ER FUENTES (2000a) Why have European herbs so successfully invaded the Chilean matorral? Effects of herbivory, soil nutrients, and fire. Journal of Arid Environments 44: 197-211.

HOLMGREN M, AM SEGURA \& ER FUENTES (2000b) Limiting mechanisms in the regeneration of the Chilean matorral: experiments on seedling establishment in burned and cleared mesic sites. Plant Ecology 147: 49-57.

HOLMGREN M (2002) Exotic herbivores as drivers of plant invasions and switch to ecosystem alternative states. Biological Invasions 4: 25-33.

HOUGH M (1995) Cities and Natural Process. Routledge, New York, New York, USA. 319 pp.

JAKSIC FM (1998) Vertebrate invaders and their ecological impacts in Chile. Biodiversity and Conservation 7: 1427-1445.

JAKSIC FM \& ER FUENTES (1980) Why are native herbs in the Chilean matorral more abundant beneath bushes: microclimate or grazing? Journal of Ecology 68: 665-669. 
JOHNSTON M, G FERNÁNDEZ \& A OLIVARES (1989) Caracterización de la germinación de seis especies de una pradera anual mediterránea. Phyton (Argentina) 50: 109-117.

JOHNSTON M, G FERNÁNDEZ \& A OLIVARES (1994) Capacidad germinativa en especies de la pradera anual mediterránea. II. Efecto del año de producción de semillas. Phyton (Argentina) 55: 59-69.

KEELEY SC \& AW JOHNSON (1977) A comparison of the pattern of herb and shrub growth in comparable sites in Chile and California. American Midland Naturalist 97: 120-132.

KOLAR CS \& DM LODGE (2001) Progress in invasion biology: predicting invaders. Trends in Ecology \& Evolution 16: 199-204.

KOWARIK I (1990) Some responses of flora and vegetation to urbanization in central Europe. In: Sukopp H, S Hejny \& I Kowarik (eds) Urban ecology: plants and plant communities in urban environments: 45-74. SPB Academic Publishing, The Hague, The Netherlands.

KREMER RG \& SW RUMMING (1996) Simulating seasonal soil water balance in contrasting semi-arid vegetation communities. Ecological Modelling 84: 151-162.

KRUGER FJ, GJ BREITENBACH, IAW MacDONALD \& DM RICHARDSON (1989) The characteristics of invaded Mediterranean-climate regions. In: Drake JR, HA Mooney, F di Castri, RH Groves, FJ Kruger, M Rejmanek and M Williamson (eds) Biological invasions: a global perspective: 181213. Wiley \& Sons, Chichester, United Kingdom.

KUNST C, S BRAVO, F MOSCOVICH. J HERRERA, J GODOY \& S VÉLEZ (2003) Fecha de aplicación de fuego y diversidad de herbáceas en una sabana de Elionorus muticus (Spreng) O. Kuntze. Revista Chilena de Historia Natural 76: 105-115.

LAILHACAR S (1986) Recursos forrajeros utilizados en producción ovina: I Zona de clima mediterráneo árido y semiárido (secano comprendido entre los valles del Elqui y Aconcagua). In: García E (ed) Producción ovina: 25-57. Universidad de Chile, Facultad de Ciencias Agrarias y Forestales, Santiago, Chile.

LAILHACAR S \& M AYLWIN (1988) Efecto de tres especies leñosas en algunas variables del suelo y del estrato herbáceo en la pradera de clima mediterráneo árido. Simiente (Chile) 58: 51-61.

LAILHACAR S \& C TORRES (2002) Influencia de los arbustos del género Atriplex L. con y sin corte de rebaje en el comportamiento del estrato herbáceo del secano árido. I: Efecto del arbusto promedio del género sobre las características cuantitativas del estrato herbáceo total. Avances en Producción Animal 26 (Chile): 79-96.

LARA A \& TT VEBLEN (1993) Forest plantations in Chile: a successful model? In: Mather A (ed) Afforestation: policies, planning and progress: 118139. Belhaven Press, London, United Kingdom.

LEWIS NB, IS FERGUSON (1993) Management of radiata pine. Inkata Press, Melbourne, Australia. $404 \mathrm{pp}$.

LODGE DM (1993) Biological invasions: lessons for ecology. Trends in Ecology and Evolution 8: 133137.

MACK RN, D SIMBERLOFF, WM LONSDALE, H EVANS, M CLOUT \& FA BAZZAZ (2000) Biotic invasions. Causes, epidemiology, global consequences, and control. Ecological Applications 10: 689-710.

MARQUET PA (2002) Metapopulations. In: HA Mooney \& JG Canadell (eds) The Earth system: biological and ecological dimensions of global environmental change: 411-420. Wiley \& Sons, Chichester, United Kingdom.

MARTICORENA C \& M QUEZADA (1985) Catálogo de la flora vascular de Chile. Gayana, Botánica (Chile) 42: 5-157.

MARTICORENA C \& M QUEZADA (1987) Adiciones a la flora de Chile. Gayana, Botánica (Chile) 44: 39-44.

MARTICORENA C \& R RODRÍGUEZ (1995) Flora de Chile. Vol. I. Pteridophyta-Gymnospermae. Universidad de Concepción, Concepción, Chile. 351 pp.

MARTICORENA C, R MATTHEI, R RODRÍGUEZ, MTK ARROYO, M MUÑOZ, FA SQUEO \& G ARANCIO (1998) Catálogo de la flora vascular de la Segunda Región (Región de Antofagasta), Chile. Gayana Botánica (Chile) 55: 23-83.

MATTHEI O (1995) Manual de las malezas que crecen en Chile. Alfabeta Impresores, Santiago, Chile. 545 pp.

MCDONNELL MJ, STA PICKETT \& RV POUYAT (1993) The application of the ecological gradient paradigm to the study of urban effects. In: McDonnell MJ \& STA Pickett (eds) Humans as components of ecosystems: 175-189. SpringerVerlag. New York, New York, USA.

MONTENEGRO G, S TEILLIER, $P$ ARCE \& V POBLETE (1991) Introductions of plants and animals into the mediterrean-type climate area of Chile. In: Groves RH \& F di Castri (eds) Biogeography of mediterranean invasions: 103-109. Cambridge University Press, Cambridge, United Kingdom.

MONTENEGRO G, $\mathrm{M}$ GÓMEZ, F DÍAZ \& $\mathrm{R}$ GINOCCHIO (2002) Regeneration potential of Chilean matorral after fire: an update view. In: Veblen T, W Baker, G Montenegro \& T Swetnam (eds) Fire and climatic change in temperate ecosystems of the western Americas: 375-403. Springer Verlag, New York, New York, USA.

MOONEY HA \& RJ HOBBS (2000) Invasive species in a changing world. Island Press, Covelo, California, USA. 435 pp.

MOONEY HA, MTK ARROYO, WJ BOND, RJ HOBBS, $S$ LAVOREL \& RP NEILSON (2001) Mediterranean ecosystems. In: Sala O \& FS Chapin (eds) Global change scenarios: 157-198. SpringerVerlag, New York, New York, USA.

MOSTNY-GLASER \& NIEMEYER-FERNÁNDEZ (1983) Museo Nacional de Historia Natural. Dirección de Bibliotecas. Archivos y Museos. Ministerio de Educación Pública, Santiago, Chile. 143 pp.

MUÑOZ MR \& FUENTES ER (1989) Does fire induce shrub germination in the Chilean matorral? Oikos 56: 177-181.

MUÑOZ-SCHICK M (1991) Crónica histórica: 100 años de la sección botánica del Museo Nacional de Historia Natural (1889-1989). Boletín del Museo Nacional de Historia Natural de Chile (Chile) 42: 181202.

MYERS N, RA MITTERMEIER, CG MITTERMEIER, GAB DA FONSECA \& J KENT (2000) Biodiversity hotspots for conservation priorities. Nature 403: 853-858.

NAVAS LE (1973) Flora de la cuenca de Santiago de Chile (Tomo I). Editorial Universitaria, Santiago, Chile. $301 \mathrm{pp}$.

NAVAS LE (1976) Flora de la cuenca de Santiago de Chile (Tomo II). Editorial Universitaria, Santiago, Chile. $559 \mathrm{pp}$.

NAVAS LE (1979) Flora de la cuenca de Santiago de Chile (Tomo III). Editorial Universitaria, Santiago, Chile. 509 pp. 
NEWSOME AE \& IR NOBLE (1986) Ecological and physiological characters of invading species. In: Groves RH \& JJ Burdon (eds) Ecology of biological invasions: 1-20. Cambridge University Press, Cambridge, United Kingdom.

NOBLE IR (1989) Attributes of invaders and the invading process: terrestrial and vascular plants. In: Drake JR, HA Mooney, F di Castri, RH Groves, FJ Kruger, M Rejmanek \& M Williamson (eds) Biological invasions: a global perspective: 301313. Wiley \& Sons, Chichester, United Kingdom.

NOVAK SJ \& RN MACK (2001) Tracing plant introduction and spread: genetic evidence from Bromus tectorum cheatgrass. BioScience 51: 114122.

OLIVARES A, M JOHNSTON \& G FERNÁNDEZ (1990) Efecto de la temperatura en la germinación de siete especies de la pradera anual mediterránea y caracterización de su emergencia. Simiente (Chile) 60: 123- 131.

OLIVARES A, M JOHNSTON \& X CONTRERAS (1994) Influencia del estrato arbóreo en la reserva de semillas del suelo. Simiente (Chile) 64: 248-253.

OLIVARES A, M JOHNSTON \& R RAMÍREZ (1999) Umbrales de temperatura y humedad en la germinación de tres especies de la pradera anual de clima mediterráneo. Agro-Ciencia (Chile) 15: 19-26.

OVALLE C, L LONGERI, J ARONSON, A HERRERA \& J AVENDANO (1996) N-2-fixation, nodule efficiency and biomass accumulation after two years in three Chilean legume trees and Tagasaste Chamaecytisus proliferus subsp palmensis. Plant and Soil 179: 131-140.

PANETTA FD (1993) A system of assessing proposed plant introductions for weed potential. Plant Protection Quarterly 8: 10-14.

PAUCHARD A \& P ALABACK (2004) Influence of elevation, land use, and landscape context on patterns of alien plant invasions along roadsides in protected areas of south-central Chile. Conservation Biology 18: 238-248.

PHILIPPI RA (1867) Sobre las plantas descritas por el padre Feuillée. Anales de la Universidad de Chile (Chile) 29: 760-775.

PHILIPPI RA (1875) Sobre las plantas que Chile posee en común con Europa. Anales de la Universidad de Chile (Chile) 47: 131-140.

PHILIPPI RA (1881) Catálogo de plantas cultivadas para el Jardín Botánico de Santiago hasta el Primero de mayo de 1881. Imprenta Nacional, Santiago, Chile. $55 \mathrm{pp}$.

PHILIPPI F (1884) Memoria i catálogo de las plantas cultivadas en el Jardín Botánico hasta el Primero de mayo de 1884. Imprenta Nacional, Santiago, Chile. 83 pp.

PICKARD J (1984) Exotic plants on Lord Howe Island: distribution in space and time 1853-1981. Journal of Biogeography 11: 181-208.

PIMENTEL D, L LACH, R ZÚNIIGA \& D MORRISON (2000) Environmental and economic costs of nonindigenous species in the United States. BioScience 50: 53-65.

POUYAT RV \& MJ MCDONNELL (1991) Heavy metal accumulation in forest soils along an urban to rural gradient in southern New York, USA. Water Air and Soil Pollution 57/58: 797-807.

PYSEK P, J SÁDLO \& B MANDÁK (2003) Czech alien flora and the historical pattern of its formation: what came first to central Europe? Oecologia 135: 122-130.

RAPOPORT EH (1993) The process of plant colonization in small settlements and large cities. In: McDonnell MJ \& STA Pickett (eds) Humans as components of ecosystems: 190-207. Springer-Verlag. New York, New York, USA

RAPOPORT EH (2000) Remarks on the biogeography of land invasions. Revista Chilena de Historia Natural 73: 367-380.

REICHARD SH \& CW HAMILTON (1997) Predicting invasions of woody plants introduced into North America. Conservation Biology 11: 193-201.

REICHE K (1896-1911) Flora de Chile. Santiago, Chile. 381, 397, 427, 489, 463, $176 \mathrm{pp}$.

REICHE K (1901) Sobre el estado actual del estudio de la botánica en Chile. Revista Chilena de Historia Natural 5: 120-124.

REJMÁNEK M \& DM RICHARDSON (1996) What attributes make some plant species more invasive? Ecology 77: 1655-1661

REJMÁNEK M (1996) Species richness and resistance to invasions. In: Orians H, R Dirzo \& JH Cushman (eds) Biodiversity and ecosystem processes in tropical forest: 153-172. Springer-Verlag, Berlin \& Heidelberg, Germany.

REJMÁNEK M (1999) Invasive plant species and invasible ecosystem. In: Sandlund T, PJ Schei \& $\AA$ Viken (eds) Invasive species and biodiversity management: 79-102. Kluwer Academic Publishers, Kluwer, The Netherlands.

REJMÁNEK M (2000) Invasive plants: approaches and predictions. Austral Ecology 25: 497-506.

RICHARDSON DM, RM COWLING \& DC LEMAITRE (1990) Assessing the risk of invasive success in Pinus and Banksia in South Africa mountain fynbos. Journal of Vegetation Science 1: 629-642.

RUDNICKY JL \& MJ MCDONNELL (1989) Forty-eight years of canopy change in a hardwood hemlock forest in New York City. Bulletin Torrey Botanical Club 116: 52-64.

RUIZ H \& JA PAVÓN (1798-1802) Flora Peruviana, et Chilensis, sive descripciones, et icones plantarum peruvianum, et chilensium, secundum systema Linnaeanum digesta, cum characteribus plurium generum evulgatorum reformatis. Madrid, España. 78, 76, $95 \mathrm{pp}$

SÁIZ F \& P OJEDA (1988) Oryctolagus cuniculus L. en Juan Fernández: problema y control. Anales del Museo de Historia Natural de Valparaíso (Chile) 14: 197-215.

SAKAI AK, FW ALLENDORF, JS HOLT, DM LODGE, J MOLOFSKY, KA WITH, S BAUGHMAN, RJ CABIN, JE COHEN, NC ELLSTRAND, DE MCCAULEY, P O'NEIL, MI PARKER, JN THOMPSON \& SG WELLER (2001) The population biology of invasive species. Annual Review of Ecology and Systematics 32: 305-332.

SALA OE, FS CHAPIN, JJ ARMESTO, E BERLOW, J BLOOMFIELD, R DIRZO, E HUBER-SANWALD, LF HUENNEKE, RB JAKSON, A KINZIG, R LEEMANS, DM LODGE, HA MOONEY, M OESTERHELD, NL POFF, MT SYKES, BH WALKER, M WALKER \& DH WALL (2000) Global biodiversity scenarios for the year 2100 . Science 287: 1770-1774.

SAX DF (2002a) Native and naturalized plant diversity are positively correlated in scrub communities of California and Chile. Diversity and Distributions 8: 193-210.

SAX DF (2002b) Equal diversity in disparate species assemblages: a comparison of native and exotic woodlands in California. Global Ecology \& Biogeography 11: 49-57.

SAX DF, SD GAINES \& JH BROWN (2002) Species invasions exceed extinctions on islands worldwide: 
a comparative study of plants and birds. American Naturalist 160: 766-783.

SMITH MD \& AK KNAPP (1999) Exotic plant species in $\mathrm{a} \mathrm{C}_{4}$-dominated grassland: invasibility, disturbance, and community structure. Oecologia 120: 605-612.

SQUEO FA, R OSORIO \& G ARANCIO (1994) Flora de los Andes de Coquimbo: Cordillera de Doña Ana. Editorial Universitaria, Santiago, Chile. 168 pp.

STOHLGREN TJ, D BINKLEY, GW CHONG, MA KALKHAN, LD SCHELL, KA BULL, Y OTSUKI, G NEWMAN, M BASHKIN \& Y SON (1999a) Exotic plant species invade hot spots of native plant diversity. Ecological Monographs 69: 25-46.

STOHLGREN TJ, LD SCHELL \& BV HEUVEL (1999b) How grazing and soil quality affect native and exotic plant diversity in Rocky Mountain grasslands. Ecological Applications 9: 45-64.

SUKOPP H (1998) Urban ecology - scientific and practical aspects. In: Breuste J, H Feldman \& O Uhlmann (eds) Urban ecology: 9-16. Springer-Verlag, Berlin \& Heidelberg, Germany.

THOMPSON K \& JP GRIME (1979) Seasonal variation in the seed banks of herbaceous species in ten contrasting habitats. Journal of Ecology 67: 893-921.

TORRES C (1999) Efecto de distintas especies y procedencias arbustivas del género Atriplex sobre el estrato herbáceo asociado en el secano costero árido de la IV Región. Tesis Ingeniero Agrónomo, Facultad de Ciencias Agronómicas, Universidad de Chile, Santiago, Chile. 115 pp.

TRABAUD L (1991) Is fire an agent favouring plant invasions? In: Groves RH \& F di Castri (eds) Biogeography of mediterranean invasions: 179. 190. Cambridge University Press, Cambridge, United Kingdom.

VAN AUKEN OW (2000) Shrub invasions of North American semiarid grasslands. Annual Review of Ecology and Systematics 31: 197-215.
VÁZQUEZ DP \& R ARAGÓN (2002) Introduction. Biological Invasions 4: 1-5.

VIDIELLA PE \& JJ ARMESTO (1989) Emergence of ephemeral plant species from soil samples of the Chilean coastal desert in response to experimental irrigation. Revista Chilena de Historia Natural 62: 99-107.

VITOUSEK PM \& LR WALTER (1989) Biological invasion by Myrica faya in Hawaii: plant demography, nitrogen fixation, ecosystem effects. Ecological Monographs 59: 247-265.

VITOUSEK PM, CM D'ANTONIO, LL LOOPE \& R WESTBROOKS (1996) Biological invasions as global environmental change. American Scientist 84: 468-478.

VON BUCH MW \& M OSORIO (1987) Probleme um die Pinus radiata-Monokulturen in Südchile. Forstarchiv 58: 249-253.

WARDLE DA, KS NICHOLSON, M AHMED \& A RAHMAN (1994) Interference effects of the invasive plant Carduus nutans $\mathrm{L}$. against the nitrogen fixation ability of Trifolium repens $\mathrm{L}$. Plant and Soil 163: 287-297.

WHEELER CT, OT HELGERSON, DA PERRY \& JC GORDON (1987) Nitrogen fixation and biomass accumulation in plant communities dominated by 'Cytisus scoparius L. in Oregon and Scotland. Journal of Applied Ecology 24: 231-237.

WHISENANT SG \& DW URESK (1990) Spring burning Japanese brome in a western wheatgrass community. Journal of Range Management 43: 205-208.

WILLIAMSON M (1996) Biological invasions. Chapman \& Hall, London, United Kingdom. 244 pp.

WISER SK, RB ALLE, PW CLINTON \& KH PLATT (1998) Community structure and forest invasion by an exotic herb over 23 years. Ecology 79: 20712081. 